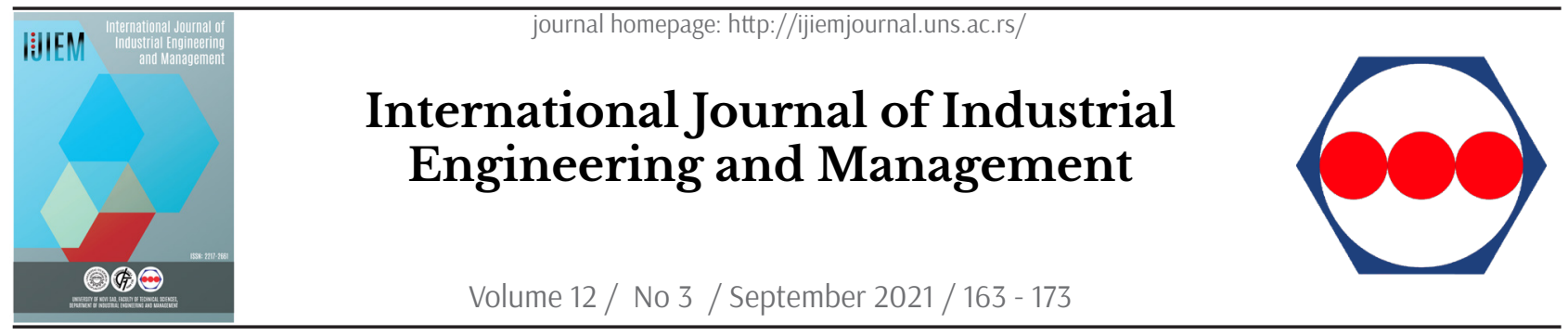

Original research article

\title{
Green Supply Chain Management and Environmental Performance: The moderating role of Firm Size
}

\author{
S. K. Fianko ${ }^{a}$, N. Amoah ${ }^{\text {b }}$, S. Afrifa Jnr ${ }^{\text {a }}$, T. C. Dzogbewu ${ }^{\text {c* }}$ \\ a Department of Business Support Studies, Central University of Technology, Bloemfontein, Free State, South Africa; \\ ${ }^{b}$ Department of Business \& law, University of Brescia, Brescia, Italy; \\ ${ }^{\mathrm{C}}$ Department of Mechanical and Mechatronic Engineering, Central University of Technology, Bloemfontein, Free State, South Africa
}

\begin{abstract}
A B STRACT
This study examined the impact of internal and external green supply chain practices on environmental performance among construction firms. The study used the quantitative survey research design in its methodology. A total of 217 employees were sampled from fifty (50) construction firms. Structural Equation Modeling was used to analyze the data. The results showed that green design does not have a significant positive relationship with environmental performance. However, green design has a positive impact on external green practices namely green purchasing and green construction. Green purchasing and green construction have direct positive relationships with environmental performance. Green design through external green practices have a significant positive relationship with environmental performance. The study found that firm size moderates the relationship between green design, through external green supply chain practices and environmental performance among construction firms.
\end{abstract}

ARTICLE INFO

Article history:

Received April 21, 2021

Revised June 5, 2021

Accepted June 8, 2021

Published online August 31, 2021

Keywords:

Green supply chain;

Green purchasing;

Green design;

Green construction;

Firm size;

*Corresponding author:

Thywill Cephas Dzogbewu

thydzo@yahoo.fr

\section{Introduction}

The rapid growth in industrialization across the world has significantly contributed to climate change due to the depletion of natural resource which has led to greenhouse gas (GHG) effect [1]. The construction industry according to The United Nations Environment Programme - Sustainable Building and Climate Initiative (UNEP-SBCI) [2] is a major contributor to this global challenge as it accounts for about $30 \%$ of the global carbon emissions, $40 \%$ generated of global waste, $30 \%$ consumption of global resources and $25 \%$ consumption of water globally. As the population that live in urban areas is antici- pated to reach $66 \%$ by 2050 , the projected emission of carbon dioxide alone is expected to reach 15.6 billion metric tons by 2030 [3, 4]. Consequently, unless immediate measures are taken towards the adoption of green construction practices and sustainable management of the supply chains in this industry, the survival of future generations cannot be guaranteed [2, 5]. Green or sustainable supply chain management refers to internal environmental management practices within a company and external environmental management initiatives with an emphasis on cooperation with all the stakeholders [6].

Green supply chain management (GSCM) prac- 
tices are categorized into two main groups which comprise internal and external green supply chain management practices [7]. GSCM is made up of internal practices which could be designed, planned, and implemented within the firm and external practices which depend on some cooperation from external parties such as suppliers and customers [7]. Internal green supply chain management practices include environmental management and eco-design/ green design. External green supply chain practices include cooperation with customers for the environment, investment recovery, green purchasing, green packaging, green construction, green production and green distribution [7]].

Literature asserts that before external green supply chain management practices can be successfully implemented it would require internal green supply chain management practices to be implemented first [9]. The implementation of green supply chain management provides several benefits including enhancement of corporate image, customer satisfaction and productivity [10]. Ait-Sidhoum and Serra [1] also indicated that green supply chain management improves operational efficiency and cost-effectiveness of firms in addition to improvement of the environment.

The literature on firm size reveals that larger firms are more positioned to perform better in terms of economic and environmental performance than small firms $[2,9,12]$. This is because large firms are capable of obtaining abundant innovative resources and also are more likely to be able to recycle materials, enhance efficiency in resources, provide green products and services, and adopt a more environmentally friendly management system than smaller firms [4, 9]. Researchers thus argue that a firm size could influence the relationship between GSCM practices and environmental performance.

While studies on green supply chain and performance have been largely explored globally $[6,11,13-$ 16], in the Ghanaian context, studies on green supply chain management and performance have received little attention and the few that have been done have focused mainly on the mining [17-19], manufacturing [12] and educational [13] sectors with little consideration to the construction industry and the moderating effect of firm size. Hsu, Chang, and Luo [14], argue that the relationship between firms' size, green supply chain management and performance in developing countries is still in its infant stage. One of the few studies in Ghana's construction was carried out by Boadu, Essuman and Nuertey [15]. The study by Boadu et al. [15] assessed the readiness of firms in the construction industry to adopt and implement green practices in their supply chains without consideration to how green supply chain management practices and firm size impacts on the performance of Ghana's construction industry. Therefore, in the quest to fill an existing gap in the literature, this study seeks to assess the moderating role of firm size on the relationship between GSCM and environmental performance in Ghana's construction industry.

This paper is organized into six different sub-sections. After the introduction, the other sections are the literature review, methodology, results, discussions and implications as well as conclusions.

\section{Theoretical background}

\subsection{Green Supply Chain Management (GSCM)}

GSCM involves the integration of environment-focused thinking in the management of the supply chain [16]. According to Carter and Rogers [17] GSCM refers to systematic coordination of the business process between an organisation and its supply chains in a strategic manner to achieve the organisation's social, environmental, and economic objectives and improve on performance in the long term. This requires that the supply chain partners apply themselves to specific criteria and adopt responsible environmental and social behaviours which enhances the whole supply chain [7]. In this study, internal GSCM is operationalised using the green design whiles external GSCM is defined by green construction and green purchasing. The selection of these GSCM practices for this study is premised on the fact that the selected GSCM practices have the capacity to bring about a reduction in the damaging effect of the organization's supply chain processes [18-20]. A brief overview of these practices follows.

\subsection{Internal Green Supply chain management Practices}

\subsubsection{Green Design}

Green designs according to Zaid et al. [19] describes planned actions introduced at the development of products which is aimed at reducing the environmental impact of a product or service right from the sourcing of raw materials till is consumed by the end-user. Green design is therefore perceived as a very critical stage due to the fact that approved constructional designs could have a substantial effect on 
the environment. Zhang et al. [20] assert that as part of the green designs in the construction industry there is a need for a thorough environmental impact assessment of the design to assess any possible effect of the building on the adjacent flora and fauna of the building. The consideration of the structure of a building, thermal characteristics and climate conditions by designers are very important in green design [19, 20]. In line with this, Zhang et al. [20] opined that such constructions (buildings) should be designed to provide natural light and ventilation in addition to the integration of technological systems such as solar panels and wastewater recycling to reduce the consumption of energy and improve the environmental performance of the building. Additionally, the right material usage such as the use of pre-fabricated components reduces waste at sites and decrease the harmful effect of the construction [21].

\subsection{External Green Supply chain management Practices (EGP)}

\subsubsection{Green Purchasing (GP)}

GP refers to the practice of taking into consideration the environmental effects in the purchasing processes and decisions making with aim of producing an environmentally friendly product and service to reduce the harmful effect of the supply chain on the environment [22]. In line with this Foo et al. [23] argue that GP sources for materials that possess harmless components and can be easily recycled or reused are the preferred sources for purchasing constructional materials. Suppliers, therefore, play a very important role in green purchasing. The integration of the green concept in purchasing thus require that organisations provide the supplier with design guideline that takes into consideration environmental issues for green purchased items [24]. Some of the activities that define green purchasing include regular audits of suppliers' environmental management system and certifications, second-tier supplier environmental evaluation, effective supplier corporation and collaboration [7, 33-34]. These activities are meant to ensure that both suppliers and focal firms conform to the best green purchasing practices.

\subsubsection{Green Construction (GC)}

The practice of engaging onsite practices in the minimization of the negative environmental impact associated with construction projects is termed green construction (GC). According to Shen and Tam [26] this practices is generally most relevant among main and sub-contractors. Some of the activities that describe the green construction practice include planning of waste management, automation of processes and wastewater recycling technology implementation $[29,30]$. Other practices that define green construction practice comprise the practice of the adopting offsite-prefabrication, highly fuel-efficient machines and the usage of materials that are very much efficient in terms of energy consumption and at the same time very low on hazardous content [29, 31-32].

\subsubsection{Environmental Performance (EP)}

Environmental performance according to Walls et al. [28] is defined as the outcome of the measure of the extent to which an organisation strategically manages the impact of its activities on the natural environment. In another definition, Younis et al. [29] referred to environmental performance as the degree to which toxic and hazardous materials are reduced, together with the reduction in environmental accidents, air emission and waste in the working environment. According to Eltayeb et al. [30] improve environmental performance in organisations imply that GSCM practices are positively impacting the organisation's natural environment. Green et al. [31] further posits that environmental performance forms the basis for the organisation's performance and competitive advantage. Several indicators for measuring environmental performance exist. For instance, ISO 1403:1999 provides EP indicators that are divided into management performance indicators (MPI), operational performance indicators (OPI) and environmental condition indicators (ECI) [32].

For this study environmental performance is measured using the following indicators; reduction in air and water pollution, reduction in consumption of energy, unsafe materials transferred impacting soil and water quality, and compliance with environmental standards. The justification for selecting these indicators lies in their wide usage in the literature $[9,36$, 38-40].

\subsection{Moderating the Effect of Firm Size}

Environmental performance of firms could be affected by firm size due to the fact that large firms have more resource and recipients of greater environmental compliance pressure from city authorities compared to firms which are smaller [34-35]. According to Jabbour et al. [33], there are differences in the approaches used by large and small firms as far as 
green supply chain management is concerned though larger firms seem to be more committed. Due to the high initial cost of green supply chain management practices, it is mostly larger firms that tend to adopt more environmentally friendly management practices as compared to smaller firms [32]. Wang, Zhang and Goh [24] examined the moderating role of firm size on the sustainable supply chain management (SSCM) practices and the sustainable performance (economic, environmental, and social) of 172 Chinese firms. The findings of the study revealed that firm size and SSCM practices have significant positive relationship with environmental and social performance. The results further revealed that the relationship between SSCM practices and economic performance is moderated by firm size. Additionally, SSCM internal practices had a significant positive impact on the economic performance of large enterprises, but not so much on the economic performance of the Small and medium enterprises.

\section{Methodology}

The study employed a quantitative survey design. The use of the quantitative survey research design was appropriate for this study since the researchers made use of numerical data to test for hypotheses on the constructs being investigated.

The choice of the quantitative survey design was to ensure the gathering of data from a larger pool of constructions firms in the Accra Metropolis and then analyze the data statistically to achieve the objectives of the study [34]. According to the database of the Association of Ghana Industries (AGI), the number of construction firms in Accra Metropolis is estimated at three hundred (300). Out of the 300 construction firms, a total of fifty (50) construction firms were randomly selected using contacts from the AGI directory to get in touch with them. A total of twelve (12) employees from each of the fifty (50) construction firms were purposefully sampled because the study had to get respondents who have in-depth knowledge about green supply chain practices and environmental issues in construction. In this regard, a total of six hundred (600) employees from the fifty (50) construction firms formed the sampling frame from which the sample size was deduced.

The sample size was chosen based on the Kregcie and Morgan [35] table for sample size determination. According to the Kregcie and Morgan [35] table, a sample size of 234 is appropriate for a population of six hundred (600). Out of the 234 questionnaires administered, a total of 217 was received, giving a re- sponse rate of $92.7 \%$. Data was gathered within four (4) months. Questionnaires served as the data collection instruments.

Environmental performance scale was adopted from Paulraj [36]. Green design scale was adopted from $\mathrm{Ng}$ et al. [37], green purchasing scale was adopted from Zhu et al. [32] and Zhu et al. [7], green construction scale was adopted from Shrestha [27]; Chen et al. [38] and Shi et al. [39].

Results from Table 1 shows that majority of respondents were males $(60.8 \%)$ while females constituted $39.2 \%$. In term of age, most respondents are between the ages of 31-35 years (39.2\%); $24.9 \%$ are between the ages of $36-40$ years; $17.1 \%$ are between 25-30 years; $12.9 \%$ are between $41-45$ years while $5.5 \%$ are more than 45 years. Regarding educational level, majority of respondents are first degree holders (57.1\%); $23.1 \%$ have masters/postgraduate degree while $19.8 \%$ have diploma/HND. The result also showed that majority of respondents have worked in construction firms for a period of 4-6 years (34.1\%); 26.3\% have worked in construction firms for more than 10 years; $24.4 \%$ have worked in construction firms for 7-10 years and $15.2 \%$ have worked in construction firms for 1-3 years. Regarding firm size, 29.5 of the respondents were from construction firms categorized as small (6-29 employees); 42.9\% of the respondents were from construction firms categorized as medium (30-99 employees) and 27.6\% were from construction firms categorized as large (more than 100 employees).

\section{Results}

\subsection{Preliminary Analysis}

A range of preliminary analyses including factor analyses and internal consistency were calculated. As may be seen in Table 2, Cronbach's alpha coefficient was calculated to assess the internal reliability of the scales used in the study. All scale recorded good Cronbach's alpha values exceeded 0.7 affirming that the scale items were reliable and hence measure precisely what they were intended to measure [40]. It is worth noting however that some of the scale items were removed before the reliability values were achieved at the exploratory factor analysis stage. An Exploratory Factor Analysis (EFA) was conducted which illustrated a Kaiser-Meyer-Olkin (KMO) sampling adequacy of 0.791 and a corresponding p-value $<.0001$ for Bartlett's Test of Sphericity. The Exploratory Factor Analysis (EFA) was necessary because all 
the scales were developed outside the current context which has differences in regards to the development and practice of the green supply chain.

Along with the EFA, a further Confirmatory Factor Analysis (CFA) was conducted. The CFA showed goodness of fit for the scale. After performing some modifications to the model, remarkable fit indices were achieved: $X^{2}=673.342, \mathrm{df}=285.314 \rho=.001$, $\mathrm{x} 2 / \mathrm{df}=2.36 ;$ RMSEA $=.044, \mathrm{RMR}=.019, \mathrm{SRMR}=$ $.043, \mathrm{CFI}=.977, \mathrm{NFI}=.973, \mathrm{GFI}=.974$. All factor loadings (regression weights) were statistically significant $(\mathrm{p}<.05)$.

Pasting the correlation values and the standardized regression tables from IBM AMOS to the [41] validity checker in the stats tool package, the following convergent and discriminant validity indices were observed. The results of the validity check are presented in table 3. It may be observed that all the average variance extracted (AVE) values were above 0.50 and construct reliabilities were also above 0.7. Accordingly, the AVE values were also greater than the square of their correlations, hence supporting discriminant validity [40].

Estimating the structural model, common method bias and multicollinearity tests were first checked before pursuing other steps in the Structural Equation Modelling (SEM) process. These checks help prevent the data from misleading a researcher into false results. To examine whether any common method bias (CMB) occurred, all indicators of the variables used in the model were presented with a common latent factor. A value of 0.509 was observed by the latent common factor. Subsequently, this value is squared to have a percentage value of $0.259=25.9 \%$ . It is doubtful that CMB exists as the value provided falls below 0.50 or $50 \%$ [42].

In addition, each of the variables were evaluated using the variance inflation factor (VIF) analysis to determine multicollinearity. Given that no variable above the critical value of 3.0 [43], it can be inferred that multi-collinearity has not been violated.

Table 1. Demographic data of respondents

\begin{tabular}{|c|c|c|}
\hline Gender & Frequency & Percentage (\%) \\
\hline Male & 132 & 60.8 \\
\hline Female & 85 & 39.2 \\
\hline Total & 217 & 100 \\
\hline \multicolumn{3}{|l|}{ Age } \\
\hline $25-30$ years & 37 & 17.1 \\
\hline 31-35 years & 86 & 39.6 \\
\hline $36-40$ years & 54 & 24.9 \\
\hline 41-45 years & 28 & 12.9 \\
\hline More than 45 years & 12 & 5.5 \\
\hline Total & 217 & 100 \\
\hline \multicolumn{3}{|l|}{ Educational Level } \\
\hline Diploma/HND & 43 & 19.8 \\
\hline First Degree & 124 & 57.1 \\
\hline Masters/Postgraduate & 50 & 23.1 \\
\hline Total & 217 & 100 \\
\hline \multicolumn{3}{|l|}{ Tenure } \\
\hline $1-3$ years & 33 & 15.2 \\
\hline 4-6 years & 74 & 34.1 \\
\hline $7-10$ years & 53 & 24.4 \\
\hline More than 10 years & 57 & 26.3 \\
\hline Total & 217 & 100 \\
\hline \multicolumn{3}{|l|}{ Firm Size } \\
\hline 6-29 employees (Small) & 64 & 29.5 \\
\hline 30-99 employees (Medium) & 93 & 42.9 \\
\hline More than 100 employees (Large) & 60 & 27.6 \\
\hline Total & 217 & 100 \\
\hline
\end{tabular}

Source: Field Data, 2021 
Table 2. Demographic data of respondents

\begin{tabular}{|c|c|c|c|c|c|}
\hline Variable & Sub variable & Source & Scale Items & $\begin{array}{l}\text { Factor } \\
\text { Loading }\end{array}$ & $\begin{array}{l}\text { Cronbach's } \\
\text { Alpha }\end{array}$ \\
\hline \multicolumn{6}{|c|}{$\begin{array}{l}\text { Internal Green } \\
\text { Practices }\end{array}$} \\
\hline & \multirow[t]{4}{*}{ Green Design } & & GD4 - Our firm provides waste water recycling & 0.698 & 0.778 \\
\hline & & & $\begin{array}{l}\text { GD6 - Our firm makes consideration for energy efficient } \\
\text { lighting system }\end{array}$ & 0.616 & \\
\hline & & & $\begin{array}{l}\text { GD8 - Our firm makes consideration for materials with } \\
\text { high recycled content and low embodied energy }\end{array}$ & 0.824 & \\
\hline & & $\begin{array}{l}\text { Ng et al. } \\
(2012)\end{array}$ & $\begin{array}{l}\text { GD10 - Our firm makes provision for the use of prefabri- } \\
\text { cated components }\end{array}$ & 0.663 & \\
\hline \multirow{9}{*}{$\begin{array}{l}\text { External } \\
\text { Green } \\
\text { Practices }\end{array}$} & & & & & 0.911 \\
\hline & \multirow[t]{5}{*}{$\begin{array}{l}\text { Green } \\
\text { Purchasing }\end{array}$} & & GP3 - Suppliers take back their packaging & 0.784 & 0.910 \\
\hline & & & GP4 - Our products are eco-labeled & 0.776 & \\
\hline & & & $\begin{array}{l}\text { GP8 - Purchases are made from suppliers who are com- } \\
\text { pliant with legislation on the environment. }\end{array}$ & 0.874 & \\
\hline & & & $\begin{array}{l}\text { GP10 - Environmental or safety information of product } \\
\text { content using green seals and indicators of relative } \\
\text { environmental impact are disclosed. }\end{array}$ & 0.773 & \\
\hline & & $\begin{array}{l}\text { Zhu et al. } \\
\text { (2007) and } \\
\text { Zhu et al., } \\
(2013)\end{array}$ & $\begin{array}{l}\text { GP11 - Suppliers are audited to evaluate compliance with } \\
\text { environmental requirements. }\end{array}$ & 0.812 & \\
\hline & \multirow[t]{3}{*}{$\begin{array}{l}\text { Green } \\
\text { Construction }\end{array}$} & & $\begin{array}{l}\text { GC3 - We use materials with high recycled content and } \\
\text { low embodied energy. }\end{array}$ & 0.700 & 0.701 \\
\hline & & & $\begin{array}{l}\text { GC6 - Automation is used for onsite construction } \\
\text { activities. }\end{array}$ & 0.472 & \\
\hline & & $\begin{array}{l}\text { Shrestha } \\
\text { (2016); Chen } \\
\text { et al. (2010); } \\
\text { Shi et al. } \\
\text { (2013) }\end{array}$ & $\begin{array}{l}\text { GC7 - Fuel efficient equipment/machinery are used at } \\
\text { project/ site. }\end{array}$ & 0.801 & \\
\hline \multicolumn{6}{|c|}{$\begin{array}{l}\text { Environmental } \\
\text { Performance }\end{array}$} \\
\hline & & & ENP2 - Greenhouse gas emissions have decreased & 0.706 & 0.886 \\
\hline & & & ENP3 - Water consumption has decreased & 0.798 & \\
\hline & & & ENP4 - Energy consumption has decreased. & 0.806 & \\
\hline & & & ENP5 - Landfill waste has decreased & 0.895 & \\
\hline & & Paulraj (2011) & ENP7 - Hazardous material use has decreased & 0.703 & \\
\hline
\end{tabular}

Table 3. Validity Statistics

\begin{tabular}{lccccccc}
\hline & CR & AVE & MSV & MaxR (H) & ENP & GD & EGP \\
\hline Environmental Performance (ENP) & 0.888 & 0.616 & 0.584 & 0.906 & 0.785 & & \\
Green Design (GD) & 0.796 & 0.696 & 0.569 & 0.817 & 0.620 & 0.834 \\
External Environmental Practices (EGP) & 0.986 & 0.972 & 0.769 & 0.953 & 0.664 & 0.777 & 0.986 \\
\hline
\end{tabular}

CR - Construct Reliability; AVE - Average Variance Extracted; MSV - Maximum Shared Variance 


\subsection{Results of Structural Equation Modelling}

After the above tests, the structural equation model was estimated testing the hypothesized relationships in the conceptual framework (Figure 1). The structural model affirmed goodness of fit: $\mathrm{X} 2=$ 753.296, $\mathrm{df}=375.446 \rho=.001, \mathrm{x} 2 / \mathrm{df}=2.006$; RM$\mathrm{SEA}=.032, \mathrm{RMR}=.019, \mathrm{SRMR}=.053, \mathrm{CFI}=.984$, $\mathrm{NFI}=.976, \mathrm{GFI}=.969$ and shows support for some of the hypothesized relationships as outlined in Table 4.

The results from the structural equation model, as shown in Table 4 and Table 5 illustrate support for the three hypotheses out of the first four. The results indicate that green design does not significantly improve the environmental performance of a firm (Green Design $\rightarrow$ Environmental Performance; $\beta=0.22$ ). However, green design has an impact on other green practices that are external to the firm in this case, green purchasing and green construction (Green Design $\rightarrow$ External green practices; $\beta=$ $\left.0.88^{* * *}\right)$. Importantly, external green practices such as green purchasing and green construction have positive impacts on environmental performance (External green practices $\rightarrow$ Environmental Performance; $\beta$ $\left.=0.57^{* * *}\right)$. Here, it may be noted that both green design and external practices have a conflicting impact on environmental performance. Since green design did not solely lead to environmental performance, it was relevant to assess whether the green design could have a significant effect on environmental performance through external green practices.

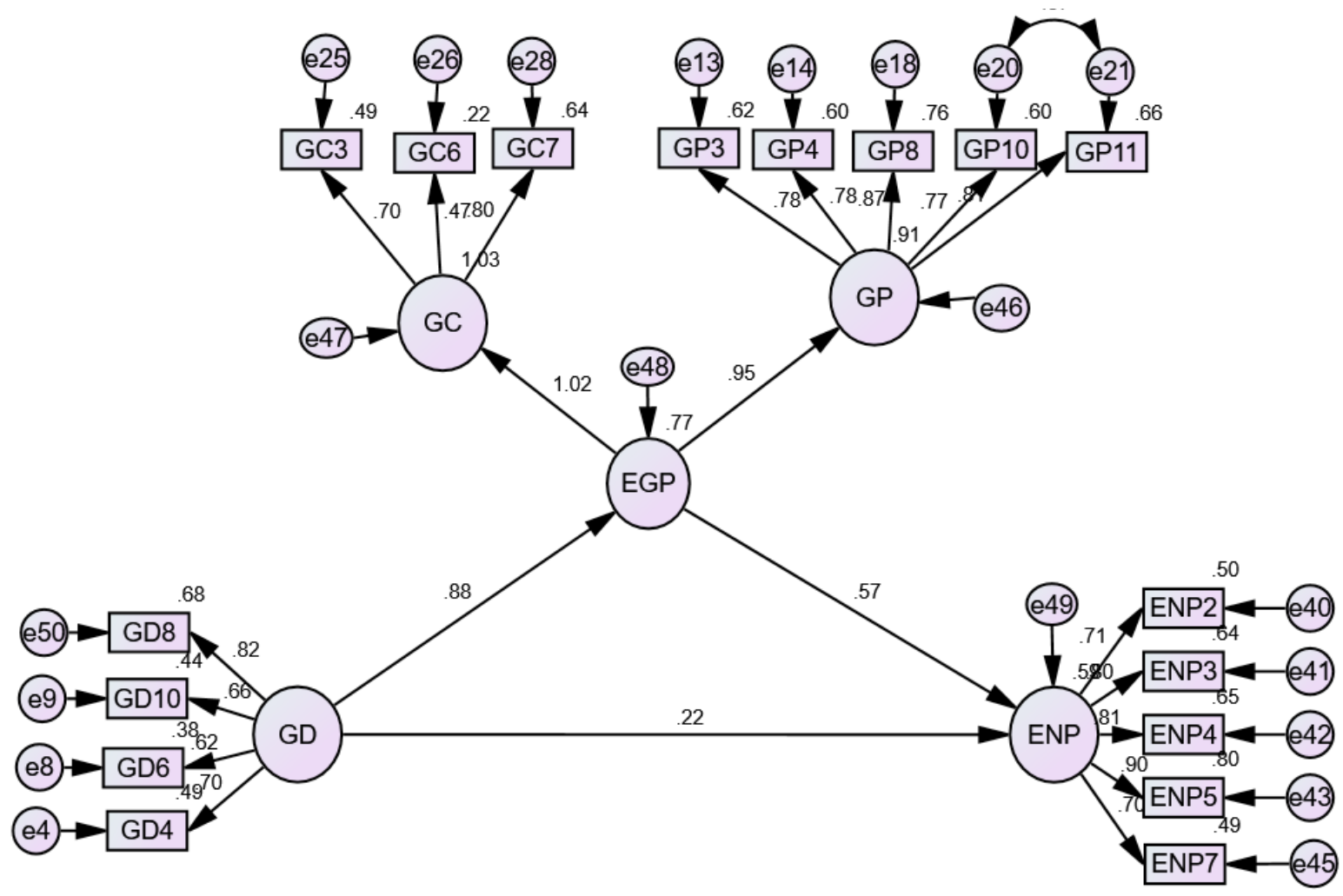

Figure 1. Structural model

Table 4. Direct effects

\begin{tabular}{llllll}
\hline Hypothesis & Path & $\begin{array}{l}\text { Standardized Path } \\
\text { Coefficient } \beta\end{array}$ & T-value & P & R2 \\
\hline $\mathrm{H} 1$ & GD $\rightarrow$ ENP & 0.218 & 1.515 & 0.13 & $* .77$ \\
$\mathrm{H} 2$ & GD $\rightarrow$ EGP & 0.877 & 10.888 & $* * *$ & $* .77$ \\
$\mathrm{H} 3$ & EGP $\rightarrow$ ENP & 0.573 & 3.904 & $* .77$ \\
\hline$* * * \mathrm{p}<0.000$ & & & &
\end{tabular}




\subsection{Mediation Analysis}

Hypotheses H4 was tested through mediation analyses. Table 5 shows the mediation effect for external green practices.

The indirect effect of external green practices through green design on environmental performance (Green Design $\rightarrow$ External Green Practices $\rightarrow$ Environmental Performance; $\beta=0.503, p=0.001$ ) was found to be significant. The bootstrapped two-tailed significant showed a p-value of 0.001 . Hence, hypothesis $\mathrm{H} 4$ was supported. The mediation is a full mediation in that the independent variable (green design) does not significantly lead to the dependent variable (environmental performance) but through the mediator (external green practices). In pursuant to the above discussions, green design will only have effect on environmental performance where there exist external green practices such as green purchasing and green construction.

\subsection{Multi-group Moderation Analysis}

Multi-group moderation test was conducted using the full model to assess the difference in the relationships between small firms and large firms. The number of employees was used to assess the size of the firm. The binary method in IBM SPSS Statistic was used to categorise the variable into small and large firms [40] to enable ease of application in IBM AMOS. To test the categorical moderation hypotheses, following Joshi and Yadav [41] a structural model with the categories of firm size (small and large) was applied. The model comparison section was checked and the chi square difference was confirmed after a chi square difference test was conducted in the stats tool pack excel sheet. The results of the structural model are summarized in the hypotheses summary Table 6 below. Since the hypothesis was to assess the difference in the relationship between green design and environmental performance, both the direct and indirect effects were analysed (representing hypothesis $5 \mathrm{a}$ and $5 \mathrm{~b}$ respectively).

Table 5. Mediation of External Green Practices

\begin{tabular}{lllll}
\hline Hypothesis & Path & $\begin{array}{l}\text { Standardized Path } \\
\text { Coefficient } \beta\end{array}$ & P value & R2 \\
\hline $\mathrm{H} 4$ & GD $\rightarrow$ EGP $\rightarrow$ ENP & 0.503 & $* *$ & 0.77 \\
\hline$* * \mathrm{p}<0.001$ & & &
\end{tabular}

Table 6. Multi group moderation analysis of direct and indirect effects based on firm size

\begin{tabular}{|c|c|c|c|c|c|c|}
\hline Hypothesis & Path & Category of firm & $\begin{array}{l}\text { Standardized } \\
\text { Path Coefficient } \\
\beta\end{array}$ & T-value & $P$ & $\mathrm{R} 2$ \\
\hline \multirow[t]{2}{*}{$\mathrm{H} 5 \mathrm{a}$} & $\begin{array}{l}\text { Direct Effect } \\
(G D \rightarrow \text { ENP) }\end{array}$ & Small Firm & 0.019 & 0.04 & 0.97 & 0.66 \\
\hline & & Large Firm & 0.322 & 1.87 & 0.06 & 0.52 \\
\hline \multirow[t]{10}{*}{$\mathrm{H} 5 \mathrm{~b}$} & $\begin{array}{l}\text { Indirect Effect } \\
(G D \rightarrow E G P \rightarrow \\
\text { ENP) }\end{array}$ & Small Firm & 0.223 & - & $* * *$ & 0.66 \\
\hline & & Large Firm & 0.363 & - & $* * *$ & 0.52 \\
\hline & Model fit indices & $\mathrm{X} 2$ & 305.356 & & & \\
\hline & & df & 135.725 & & & \\
\hline & & $\mathrm{sq} / \mathrm{df}$ & 2.250 & & & \\
\hline & & $\mathrm{P}$ & 0.000 & & & \\
\hline & & GFI & 0.975 & & & \\
\hline & & CFI & 0.991 & & & \\
\hline & & RMSEA & 0.039 & & & \\
\hline & & PCLOSE & 0.012 & & & \\
\hline
\end{tabular}


The results in Table 6 indicate that in both cases, the green design does not significantly lead to environmental performance $(\beta=0.019$ and $\beta=0.322)$ for small firms and large firms respectively. This result renders H5a unsupported because, even though there are differences in the regression weights, the relationships are insignificant.

For the indirect effects, however, the hypothesis (H5b) was supported $\left(\beta=0.223^{* * *}\right.$ and $\beta=0.363^{* * *}$ for small firms and large firms respectively). It was found that the effect of green design on environmental performance through external green practices was higher for the larger firms than for the smaller firms.

\section{Discussion and Conclusion}

The study examined internal and external green supply chain practices and their impact on environmental performance in the construction industry in Ghana. The study also examined the moderating role of firm size on the relationship between green supply chain practices and environmental performance. The study found that there is no significant relationship between internal green supply chain (green design) and environmental performance among Ghanaian construction firms. This finding was in contrast with a study conducted by Balasubramanian and Shukla [44] which found that a significant positive relationship exists between green design and environmental performance. The findings on green design and its impact on environmental performance was also in contrast with a study by Younis, Sundarakani and Vel [29] who found a significant positive relationship between green design and environmental performance. However, the findings on green design and environmental performance in the Ghanaian construction industry was consistent with a study conducted by Epoh and Mafini [45] who also found that no significant relationship exists between green design and environmental performance.

On external green supply chain practices, the study found that green construction and green purchasing have significant positive relationships with environmental performance in the Ghanaian construction industry. This finding was consistent with previous studies which also establishes that green purchasing and green construction have significant positive relationships with environmental performance [29, 44, 46].

This study makes important contributions to research on green supply chain practices and its impact on environmental performance. This is because, al- though previous studies have only focused their attention on the direct effects of green supply chain practices on environmental performance, this study went further to analyze the indirect effects among internal and external green supply chain practices, firm size and environmental performance. The findings of the study indicate that construction firms in Ghana cannot achieve environmental performance by applying only green design which is an indicator of internal green supply chain. Rather, construction firms can achieve environmental performance when green design is linked to external green supply chain practices such as green purchasing and green construction. This implication corroborates with literature that asserts that before external green supply chain management practices can be successfully implemented it would require internal green supply chain management practices to be implemented first [33].

The study examine the moderating impact of firm size on the relationship between internal and external green supply chains and environmental performance among Ghanaian construction firms. The study found that internal green supply chain cannot independently enhance environmental performance unless it is connected to external green supply chain practices. The study also found that firm size does not moderate the direct relationship between internal green supply chain and environmental performance. Rather, firm size moderates the relationship between internal green supply chain practices through external green supply chain practices in order to enhance environmental performance among Ghanaian construction firms. The study contributes to academic novelty as it established both the direct and indirect effects among the constructs of the study using structural equation modelling as most previous studies have only assessed the unilateral relationships between green supply chain practices and environmental performance without paying attention to multiple relationships and moderation effects.

The implication to management of construction firms, is that, in their efforts to achieve environmental performance, there is the need to integrate internal green supply chain practices such as green design with external green supply chain practices such as green purchasing and green construction. The study's findings further imply that the size of the firm, either small or large does not enhance the achievement of environmental performance with the application of internal green supply chain practices (green design) alone. Rather, the achievement of environmental performance through the application of green 
supply chain practices is determined by the integration of green design with other external green supply chain practices such as green purchasing and green construction. The study's finding also conforms to the literature on firm size which stipulates that larger firms, rather than smaller firms are more positioned to perform better in terms of economic and environmental performance with the application of internal and external green supply chains [24]. Based on the findings and their related implications, the study recommends the need for construction firms to adopt and implement green supply chain practices by ensuring integration of both internal and external green supply chain practices in order to achieve environmental performance.

\section{Funding}

This work is based on research supported by the Collaborative Program in Additive Manufacturing [Contract № CSIR-NLC-CPAM-18-MOA-CUT-01].

\section{References}

[1] A. Ait Sidhoum and T. Serra, "Corporate Sustainable Development. Revisiting the Relationship between Corporate Social Responsibility Dimensions," Sustain. Dev., vol. 26, no. 4, pp. 365-378, 2018, doi: 10.1002/sd.1711.

[2] UNEP-SBCI, "UNEP-SBCI releases its latest report on 'Greening the Building Supply Chain."' https://www.construction21.org/articles/h/unep-sbcireleases-its-latest-report-on-greening-the-building-supplychain.html (accessed Apr. 21, 2021).

[3] M. Levine, D. Ürge-Vorsatz, K. Blok, L. Geng, D. Harvey, S. Lang, G. Levermore, A. Mongameli Mehlwana, S. Mirasgedis, A. Novikova, J. Rilling, and H.M. Yoshino. "Residential and commercial 1 buildings Coordinating Lead Authors: Lead Authors: Contributing Authors: Review Editors: This chapter should be cited as," in Climate Change 2007: Mitigation. Contribution of Working III to the Fourth Assessment, France, 2007, pp. 387-446.

[4] United Nations, "World Urbanization Prospects, The 2014 Revision," 2015.

[5] H. Walker and N. Jones, "Sustainable supply chain management across the UK private sector," Supply Chain Manag., vol. 17, no. 1, pp. 15-28, Jan. 2012, doi: 10.1108/13598541211212177.

[6] W. Yu, R. Chavez, M. Feng, and F. Wiengarten, "Integrated green supply chain management and operational performance," Supply Chain Manag., vol. 19, no. 5/6, pp. 683-696, Sep. 2014, doi: 10.1108/SCM-07-2013-0225.

[7] Q. Zhu, J. Sarkis, and K. hung Lai, "Institutional-based antecedents and performance outcomes of internal and external green supply chain management practices," J. Purch. Supply Manag., vol. 19, no. 2, pp. 106-117, Jun. 2013, doi: 10.1016/j.pursup.2012.12.001.

[8] C. Mafini and A. Muposhi, "The impact of green supply chain management in small to medium enterprises: Cross-sectional evidence,” J. Transp. Supply Chain Manag., vol. 11, Feb. 2017, doi: 10.4102/jtscm.v11i0.270.
[9] S. M. Diab, F. A. AL-Bourini, and A. H. Abu-Rumman, "The Impact of Green Supply Chain Management Practices on Organizational Performance: A Study of Jordanian Food Industries,” J. Manag. Sustain., vol. 5, no. 1, Feb. 2015, doi: 10.5539/jms.v5n1p149.

[10] S. Yildiz Çankaya and B. Sezen, "Effects of green supply chain management practices on sustainability performance," J. Manuf. Technol. Manag., vol. 30, no. 1, pp. 98-121, 2019, doi: 10.1108/JMTM-03-2018-0099.

[11] S. Kusi-Sarpong, J. Sarkis, and X. Wang, "Assessing Green Supply Chain Practices in the Ghanaian Mining Industry: A Framework and Evaluation." International Journal of Production Economics, 181, 325-341

[12] E. Afum, V. Y. Osei-Ahenkan, Y. Agyabeng-Mensah, J. Amponsah Owusu, L. Y. Kusi, and J. Ankomah, "Green manufacturing practices and sustainable performance among Ghanaian manufacturing SMEs: the explanatory link of green supply chain integration," Manag. Environ. Qual. An Int. J., vol. 31, no. 6, pp. 1457-1475, Jul. 2020, doi: 10.1108/MEQ-01-2020-0019.

[13] S. Famiyeh, A. Kwarteng, D. Asante-Darko, and S. A. Dadzie, "Green supply chain management initiatives and operational competitive performance," Benchmarking, vol. 25, no. 2, pp. 607-631, 2018, doi: 10.1108/BIJ-10-20160165.

[14] C. H. Hsu, A. Y. Chang, and W. Luo, "Identifying key performance factors for sustainability development of SMEs - integrating QFD and fuzzy MADM methods," J. Clean. Prod., vol. 161, pp. 629-645, Sep. 2017, doi: 10.1016/j.jclepro.2017.05.063.

[15] P. Boadu, S. C. Analyst, C. Team, D. Essuman, D. Nuertey, and K. Nkrumah, "Embracing Green Supply Chain Practices In The Construction Industry, The Case Of Construction Firms In The Kumasi Metropolis And Its Environs,” Res. J. Manag., vol. 2, no. 6, pp. 1-17, 2014.

[16] U. Mumtaz, Y. Ali, A. Petrillo, and F. De Felice, "Identifying the critical factors of green supply chain management: Environmental benefits in Pakistan," 2018, doi: $10.1016 /$ j.scitotenv.2018.05.231.

[17] C. R. Carter and D. S. Rogers, "A framework of sustainable supply chain management: Moving toward new theory," International Journal of Physical Distribution and Logistics Management, vol. 38, no. 5. Emerald Group Publishing Limited, pp. 360-387, 2008, doi: 10.1108/ 09600030810882816.

[18] A. J. Acevedo-Urquiaga, N. Sablón-Cossío, J. A. Acevedo-Suárez, and A. J. Urquiaga-Rodríguez, "A model with a collaborative approach for the operational management of the supply chain,” Int. J. Ind. Eng. Manag., vol. 12, no. 1, pp. 49-62, 2021, doi: 10.24867/ IJIEM-2020-1-276.

[19] A. A. Zaid, A. A. M. Jaaron, and A. Talib Bon, "The impact of green human resource management and green supply chain management practices on sustainable performance: An empirical study,” J. Clean. Prod., vol. 204, pp. 965-979, Dec. 2018, doi: 10.1016/j.jclepro.2018.09.062.

[20] X. Zhang, L. Shen, and Y. Wu, "Green strategy for gaining competitive advantage in housing development: A China study,” J. Clean. Prod., vol. 19, no. 2-3, pp. 157-167, Jan. 2011, doi: 10.1016/j.jclepro.2010.08.005.

[21]J. Ying Liu, S. Pheng Low, and X. He, "Green practices in the Chinese building industry: drivers and impediments," J. Technol. Manag. China, vol. 7, no. 1, pp. 50-63, Feb. 2012, doi: 10.1108/17468771211207349.

[22] J. Shao and E. Ünal, "What do consumers value more in green purchasing? Assessing the sustainability practices from demand side of business," J. Clean. Prod., vol. 209, pp. 1473-1483, Feb. 2019, doi: 10.1016/j.jclepro. 2018.11.022. 
[23] M. Y. Foo, K. Kanapathy, S. Zailani, and M. R. Shaharudin, "Green purchasing capabilities, practices and institutional pressure," Manag. Environ. Qual. An Int. J., vol. 30, no. 5, pp. 1171-1189, Aug. 2019, doi: 10.1108/ MEQ-07-2018-0133.

[24] J. Wang, Y. Zhang, and M. Goh, "Moderating the role of firm size in sustainable performance improvement through sustainable supply chain management," Sustain., vol. 10, no. 5, May 2018, doi: 10.3390/su10051654.

[25] Q. Zhu, J. Sarkis, and Y. Geng, "Green supply chain management in China: pressures, practices and performance,” Int. J. Oper. Prod. Manag., vol. 25, no. 5, pp. 144-3577, 2005, doi: 10.1108/01443570510593148.

[26] L. Y. Shen and V. W. Y. Tam, "Implementation of environmental management in the Hong Kong construction industry,” Int. J. Proj. Manag., vol. 20, no. 7, pp. 535-543, Oct. 2002, doi: 10.1016/S0263-7863(01)00054-0.

[27] S. Shrestha, "Comparison of energy efficient and green buildings : technological and policy aspects with case studies from Europe, the USA, India and Nepal,” 2016, doi: 10.14279/DEPOSITONCE-4948.

[28] J. L. Walls, P. Berrone, and P. H. Phan, "Corporate governance and environmental performance: is there really a link?,” Strateg. Manag. J., vol. 33, no. 8, pp. 885-913, Aug. 2012, doi: 10.1002/smj.1952.

[29] H. Younis, B. Sundarakani, and P. Vel, "The impact of implementing green supply chain management practices on corporate performance," Compet. Rev., vol. 26, no. 3, pp. 216-245, 2016, doi: 10.1108/CR-04-2015-0024.

[30] T. K. Eltayeb, S. Zailani, and T. Ramayah, "ARTICLE IN PRESS Green supply chain initiatives among certified companies in Malaysia and environmental sustainability: Investigating the outcomes,” 2010, doi: 10.1016/j.resconrec.2010.09.003.

[31] K. W. Green Jr, P. J. Zelbst, J. Meacham, and V. S. Bhadauria, "Green supply chain management practices: impact on performance,” An Int. J., vol. 17, pp. 290-305, 2012, doi: 10.1108/13598541211227126.

[32] Q. Zhu, J. Sarkis, and K. hung Lai, "Confirmation of a measurement model for green supply chain management practices implementation,” Int. J. Prod. Econ., vol. 111, no. 2, pp. 261-273, Feb. 2008, doi: 10.1016/j.jjpe.2006.11.029.

[33] A. B. L. de Sousa Jabbour, F. C. D. O. Frascareli, and C. J. C. Jabbour, "Green supply chain management and firms' performance: Understanding potential relationships and the role of green sourcing and some other green practices," Resour. Conserv. Recycl., vol. 104, pp. 366-374, Nov. 2015, doi: 10.1016/j.resconrec.2015.07.017.

[34] J. W. Creswell, Qualitative enquiry \& research design, choosing among five approaches, vol. 2nd ed. 2007.

[35] R. V. Krejcie and D. W. Morgan, "Determining Sample Size for Research Activities,"Educ.Psychol. Meas.,vol.30, no. 3, pp. 607-610, Sep. 1970, doi: 10.1177/ 001316447003000308 .

[36] A. Paulraj, "Understanding the relationships between internal resources and capabilities, sustainable supply management and organizational sustainability," J. Supply Chain Manag., vol. 47, no. 1, pp. 19-37, Jan. 2011, doi: 10.1111/j.1745-493X.2010.03212.x.

[37] S. T. Ng, J. M. W. Wong, S. Skitmore, and A. Veronika, "Carbon dioxide reduction in the building life cycle: A critical review," in Proceedings of the Institution of Civil Engineers: Engineering Sustainability, Dec. 2012, vol. 165, no. 4, pp. 281-292, doi: 10.1680/ensu.11.00005.

[38] Y. Chen, G. E. Okudan, and D. R. Riley, "Sustainable performance criteria for construction method selection in concrete buildings," Autom. Constr., vol. 19, no. 2, pp. 235-244, Mar. 2010, doi: 10.1016/j.autcon.2009.10.004.
[39] Q. Shi, J. Zuo, R. Huang, J. Huang, and S. Pullen, "Identifying the critical factors for green construction - An empirical study in China," Habitat Int., vol. 40, pp. 1-8, Oct. 2013, doi: 10.1016/j.habitatint.2013.01.003.

[40] J. Pallant, S. Sands, and I. Karpen, "Product customization: A profile of consumer demand," J. Retail. Consum. Serv., vol. 54, p. 102030, May 2020, doi: 10.1016/j. jretconser.2019.102030.

[41] R. Joshi and R. Yadav, "Captivating Brand Hate Using Contemporary Metrics: A Structural Equation Modelling Approach," Vision, p. 097226291989217, Jan. 2020, doi: 10.1177/0972262919892173.

[42] C. Ranaweera and C. Jayawardhena, "Talk up or criticize? Customer responses to WOM about competitors during social interactions,” J. Bus. Res., vol. 67, no. 12, pp. 26452656, Dec. 2014, doi: 10.1016/j.jbusres.2014.04.002.

[43] J. F. Hair, C. M. Ringle, and M. Sarstedt, "Editorial - Partial Least Squares Structural Equation Modeling: Rigorous Applications, Better Results and Higher Acceptance by Joseph F. Hair, Christian M. Ringle, Marko Sarstedt:: SSRN,” Long Range Planning, Volume 46, Issues 1-2, 2013. https://papers.ssrn.com/sol3/papers.cfm?abstract_ id=2233795 (accessed Apr. 21, 2021).

[44] S. Balasubramanian and V. Shukla, "Green supply chain management: an empirical investigation on the construction sector," Supply Chain Manag. An Int. J., vol. 22, no. 1, pp. 58-81, Jan. 2017, doi: 10.1108/SCM-07-2016-0227.

[45] L. R. Epoh and C. Mafini, "Green supply chain management in small and medium enterprises: Further empirical thoughts from South Africa," J. Transp. Supply Chain Manag., vol. 12, Jun. 2018, doi: 10.4102/jtscm. v12i0.393. 